\title{
EFFECTS OF IL-17 ON FUNCTIONAL ACTIVITY OF PERIPHERAL BLOOD CELLS
}

VLAŠKI MARIJA, KRSTIĆ ALEKSANDRA, JOVČIĆ GORDANA, BUGARSKI DIANA, PETAKOV MARIJANA, STOJANOVIĆ NEVENKA and MILENKOVIĆ P

Institute for Medical Research, Belgrade

(Received 4. April 2004)

Interleukin-17 (IL-17) is a proinflammatory cytokine produced mainly by activated $C D 4^{+}$and $C D 8^{+} T$ cells, while its specific receptor is ubiquitously distributed. The inflammatory capacity of IL-17 is based on its ability to stimulate a wide range of stromal cells to produce and release a number of proinflammatory mediators, some with a known impact on hematopoiesis, particularly granulopoiesis. Recent data indicate a role for $I L-17$ in the pathogenesis of several inflammatory diseases, transplant rejection and tumor growth. The purpose of this study was to determine functional responses, including the respiratory burst, nitric oxide (NO) production, adhesiveness and metabolical activity/viability of human peripheral blood leukocytes (total white blood cells, mononuclear cells and granulocytes) from healthy donors in the presence of recombinant human ( $r$ h) IL-17. The obtained results showed that rhlL-17 did not induce significant changes in the respiratory burst, NO production, and metabolical activity of each peripheral blood cell fraction the tested, while a slight increase in phorbol-12-myristate-13-acetate (PMA) stimulated adhesiveness of granulocytes and mononuclear cells was noted. The absence of significant changes in tested functional activities of various peripheral blood cells suggests that IL-17 does not express its proinflammatory ability in steady-state, since the requirement for its action really does not exist. activity

Key words: cytokines, IL-17, inflammation, leukocyte functional

\section{INTRODUCTION}

IL-17 is a newly described cytokine, first identified as the human homolog of cytotoxic T lymphocyte-associated antigen 8, CTLA-8 (Rouvier et al., 1993). Since CTLA-8 displayed some of the features of cytokine genes, such as the predicted hydrophobic $\mathrm{NH}_{2}$-terminal sequence which could correspond to a signal peptide, and the presence of a 3' untranslated region of AU rich repeats associated with mRNA instability, it was subsequently renamed as IL-17. IL-17 is recognized as the prototype member of an emerging cytokine family, comprising least six members (IL-17 A, B, C, D, E, F), which together with the cognate receptors represent a 
unique signaling system that appears to be highly conserved across vertebrate evolution (Aggarwal and Gurney, 2002). Human IL-17 is a 20-30 kDa homodimeric, variably glycosylated polypeptide mainly produced by activated $\mathrm{CD}^{+}$and $\mathrm{CD}^{+} \mathrm{T}$ cells, mostly of the memory CD45RO ${ }^{+}$subset (Fossiez et al., 1998). In contrast to its apparently restricted expression, the receptor for IL-17 shows an almost ubiquitous cellular distribution (Yao et al., 1997).

IL-17 exhibits pleiotropic biological activities, attributed mostly to its ability to stimulate production of numerous biologically active molecules by a variety of cells, among which are hematopoietic and proinflammatory cytokines (Fossiez et al., 1996). Accumulating evidence has shown that IL-17 is an important mediator of inflammation, especially in neutrophil-dominated responses to bacterial challenge (Witowski et al., 2004). Nevertheless, even the first data indicated that IL-17 provides a link between T-cell immune responses and hematopoietic system. In their seminal paper Fossiez et al. (1996) demonstrated that IL-17 sustained the proliferation of human $\mathrm{CD} 34^{+}$hematopoietic progenitors and their maturation into neutrophils in vitro, only in the presence of the fibroblast feeder layer. In addition, IL-17 overexpression in vivo induced granulopoiesis in mice (Schwarzenberger et al., 1998).

Recent data support a role for IL-17 in the pathogenesis of several inflammatory diseases, transplant rejection and tumor growth (Schwarzenberger and Kolls, 2002). Elevated levels of IL-17 have been found in the synovial fluid from rheumatoid arthritis patients, in sputum and bronchoalveolar fluid in asthma as well as in colorectal tissues and serum of subjects with active inflammatory bowel disease (Kotake et al., 1999; Molet et al., 2001; Fujino et al., 2003). Its mRNA expression was increased in mononuclear cells in multiple sclerosis (Matusevicius et al., 1999) and in T lymphocytes isolated from psoriatic and atopic contact dermatitis lesions (Albanesi et al., 1999; Teunissen et al., 1998). It has been postulated that its contribution to these inflammatory processes is exerted by stimulation of a wide range of stromal cells to produce and release a number of proinflammatory mediators (Witowski et al., 2004; Aggarwal and Gurney, 2002), among which are those that attract leukocytes, predominantly neutrophils, to the site of inflammation (IL-8, GRO $\alpha, \mathrm{GCP}-2, \mathrm{MCP}-1)$, activate their effector functions (IL-1 $\beta$, TNF $\alpha$ ) or stimulate granulopoiesis in bone marrow (IL-6, G-CSF, GM-CSF).

It is well known that upon stimulation the functional responses of activated leukocytes differ depending on the leukocyte cell subset and in addition to production of cytokines and other inflammatory mediators, may include shape change, adhesion, aggregation, chemotaxis, degranulation, phagocytosis and respiratory burst. The aim of this study was to analyze the effects of IL-17 on human peripheral blood leukocytes obtained from healthy volunteers. The respiratory burst, nitric oxide (NO) production, adhesiveness and metabolical activity/viability of total white blood cells (WBC), as well as granulocytes and mononuclear cell populations were investigated. 
Acta Veterinaria (Beograd), Vol. 54. No. 4, 249-261, 2004.

\section{MATERIAL AND METHODS}

\section{Separation of peripheral blood cells}

Peripheral blood was obtained from healthy persons. Separation of WBC was performed by mixing 6\% HES (Hydroxyethylstarke, Plasmasteril, Frasenius, Hamburg, Germany) with heparinized venous peripheral blood at 1:7 ratio, followed by centrifugation at 2700rpm for $15 \mathrm{~min}$. Peripheral blood mononuclear cells and granulocytes were separated using an isotonic discontinuous Percoll gradient (Amersham Pharmacia Biotech, Uppsala, Sweden). Heparinized peripheral blood was diluted with $0.15 \mathrm{M} \mathrm{NaCl}$ at the ratio of $1: 1$ and over layered on Percoll solutions of specific gravity 1.09 and $1.07 \mathrm{~g} / \mathrm{ml}$. After centrifugation at $1300 \mathrm{rpm}$ for $30 \mathrm{~min}$ at room temperature, mononuclear cell and granulocyte layers were recovered and subsequently removed. The remaining erythrocytes in the isolated cell fractions were lysed using isotonic $\mathrm{NH}_{4} \mathrm{Cl}$ solution $(155 \mathrm{mM}$ $\mathrm{NH}_{4} \mathrm{Cl}, 10 \mathrm{mM} \mathrm{KHCO} 3,0.1 \mathrm{mM}$ EDTA, pH 7.4). Separated WBC, mononuclear cells and granulocytes were washed twice in Dulbecco's modified Eagle's medium (DMEM, Sigma Chemicals Co., St. Louis, Mo., USA) and suspended in DMEM supplemented with $10 \%$ fetal calf serum (FCS, Sigma Chemicals Co., St. Louis, Mo., USA) to a concentration of $5 \times 10^{6} \mathrm{cells} / \mathrm{ml}$. The purity of mononuclear and granulocyte cell fractions was more than $98 \%$, as determined by MayGrünwald-Giemsa staining.

\section{NBT reduction assay}

The activation of each isolated peripheral blood cell fraction was evaluated by cytochemical assay for the respiratory burst (Monboisse et al., 1991), measured by the intracellular reduction of nitroblue tetrazolium salt (NBT, Merck, Germany). Increasing concentrations of rhlL-17 (0, 50, 100, $500 \mathrm{ng} / \mathrm{ml})(\mathrm{R} \& D$ Systems, Minneapolis, MN, USA) and NBT (10 $\mu \mathrm{l}, 5 \mathrm{mg} / \mathrm{ml})$ were added to each cell suspension tested $\left(5 \times 10^{5}\right.$ cells/well, $\left.100 \mu \mathrm{l}\right)$, plated in 96-well plates and incubated for $30 \mathrm{~min}$. For the measurement of spontaneous or stimulated NBT reduction, cells were incubated in medium only or in the presence of $50 \mathrm{ng} / \mathrm{ml}$ PMA (Sigma Chemicals Co., St. Louis, Mo., USA), respectively. Formazan produced by the cells was extracted overnight in $10 \%$ SDS- $0.1 \mathrm{~N} \mathrm{HCl}$ at $37^{\circ} \mathrm{C}$ and was measured spectrophotometrically at $540 \mathrm{~nm}$ in an ELISA 96-well plate reader (Labsystems Multiskan PLUS, Finland).

\section{Measurement of nitric oxide production}

WBC, mononuclear cells or granulocytes were plated, in 96-well plates $\left(5 \times 10^{5}\right.$ cells/well, $\left.100 \mu \mathrm{l}\right)$ along with increasing concentrations of rhlL-17 $(0,50$, $100,500 \mathrm{ng} / \mathrm{ml}$ ) and cultivated for $24 \mathrm{~h}$ in the presence or absence of $1000 \mathrm{ng} / \mathrm{ml}$ LPS (lipopolysaccharide from E. coli, serotype 055: B5 strain; Sigma Chemicals Co., St. Louis, Mo., USA). Production of nitric oxide, quantified by the accumulation of nitrite in the $24 \mathrm{~h}$ culture medium, was measured spectrophotometrically using the Griess reaction with sodium nitrite as standard (Green et al., 1982). Briefly, $50 \mu \mathrm{l}$ of culture supernatants were mixed with equal 
volumes of $1 \%$ sulfanilamide (Sigma Chemicals Co., St. Louis, Mo., USA) in 5\% $\mathrm{H}_{3} \mathrm{PO}_{4}$ and $0.1 \% \quad \mathrm{~N}$-1-naphthylethylene diamine dihydrochloride (Sigma Chemicals Co., St. Louis, Mo., USA) in distilled water and after $10 \mathrm{~min}$ at room temperature, the absorbance at $540 \mathrm{~nm}$ was measured.

\section{Measurement of adhesion}

Adhesion of peripheral blood cells to plastic was assessed using a modified assay initially described by Oez et al. (1990). Peripheral blood cells were plated $\left(5 \times 10^{5} \mathrm{cells} /\right.$ well, $\left.100 \mu \mathrm{l}\right)$ in 96-well plates in the presence of rhlL-17 $(0,50,100$, $500 \mathrm{ng} / \mathrm{ml}$ ) and incubated for $60 \mathrm{~min}$. For the measurement of spontaneous or stimulated adhesion, cells were incubated in medium only (spontaneous adhesion), or in the presence of $50 \mathrm{ng} / \mathrm{ml} \mathrm{PMA}$ (stimulated adhesion). After this incubation, non-adherent cells were carefully removed by sequentially adding and aspirating the saline three times. Cells adhering to the plastic surface were fixed with methanol for $8 \mathrm{~min}$ and then stained with $0.1 \%$ crystal violet for $10 \mathrm{~min}$ at room temperature. The plates were washed three times in running water and left to air dry. The dye was dissolved in $200 \mu \mathrm{l}$ of $33 \%$ acetic acid and the absorbance was measured at $540 \mathrm{~nm}$ in an ELISA 96-well plate reader.

\section{MTT assay}

Metabolic activity/viability of the peripheral blood cells was analyzed by a quantitative colorimetric assay in which 3-(4,5-dimethyl-thiazol-2yl)-2,5 diphenyltetrazolium bromide (MTT, ICN Biomedicals, Ohio, USA) was metabolically reduced to the colored end product, formazan (Mosmann et al., 1983). The MTT assay was conducted with freshly isolated cells in the presence of increasing concentrations of rhlL-17 $(0,50,100,500 \mathrm{ng} / \mathrm{ml})$. WBC, mononuclear cells or granulocytes were added to the wells $\left(5 \times 10^{5} \mathrm{cells} /\right.$ well, $\left.100 \mu \mathrm{l}\right)$ of 96 -well plates. Immediately, MTT $(10 \mu \mathrm{l}, 5 \mathrm{mg} / \mathrm{ml})$ was added and the cultures were incubated for $3 \mathrm{~h}$ at $37^{\circ} \mathrm{C}$ in a humidified atmosphere. Formazan produced by the cells was dissolved during overnight incubation in SDS-HCl $(10 \%$ SDS- $0.1 \mathrm{~N} \mathrm{HCl}$ ) and subsequently its absorbance was measured at $540 \mathrm{~nm}$ in an ELISA 96-well plate reader.

Data display and statistical analysis

Each test for every isolated peripheral blood cell fraction was performed at least three times. Statistical analysis was performed by Student's t-test, using the Origin PC Program with the actual numbers of each investigated parameter. A p value less than 0.05 was considered significant.

\section{RESULTS}

Effect of IL-17 on NBT reduction by peripheral blood cells

The respiratory burst activity of peripheral blood cells upon stimulation with rhlL-17 $(0,50,100,500 \mathrm{ng} / \mathrm{ml})$ was evaluated by a cytochemical test for respiratory 
Acta Veterinaria (Beograd), Vol. 54. No. 4, 249-261, 2004.

burst based upon the capacity of cells to reduce NBT (Monboisse et al., 1991). NBT reduction occurs by a chemical reaction between the dye and the superoxide anion $\left(\mathrm{O}_{2}^{-}\right)$generated by the activated respiratory burst NADPH oxidase. No significant changes in spontaneous NBT reduction by WBC, peripheral granulocytes and mononuclear cells were detected. in the presence of increasing concentrations of rhlL-17. However, the responses to IL-17 given by mononuclear cells and granulocytes were up to $20 \%$ higher in comparison to the spontaneous NBT reduction observed in medium only. PMA-stimulated NBT reduction by all tested peripheral blood cells was not affected significanlty in the presence of rhIL17 (Figure 1).

A

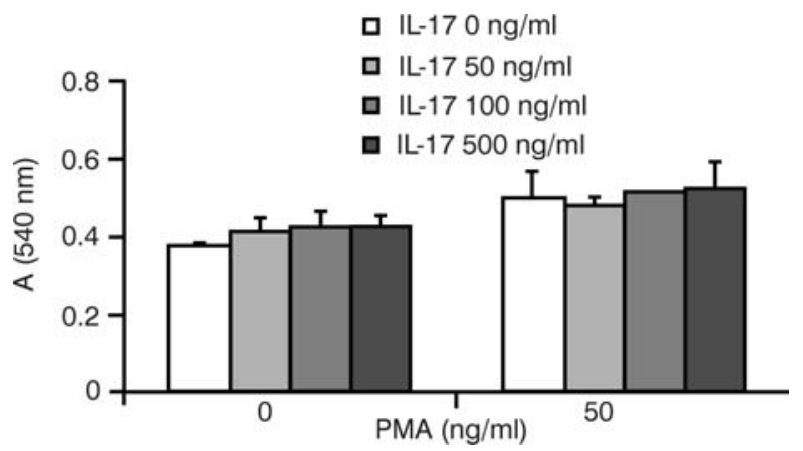

B

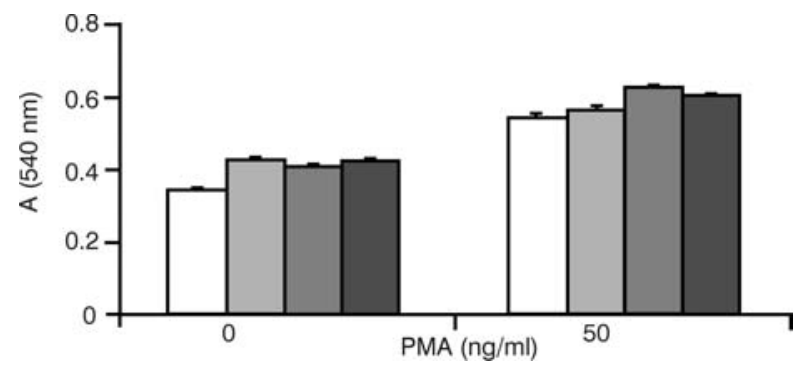

C

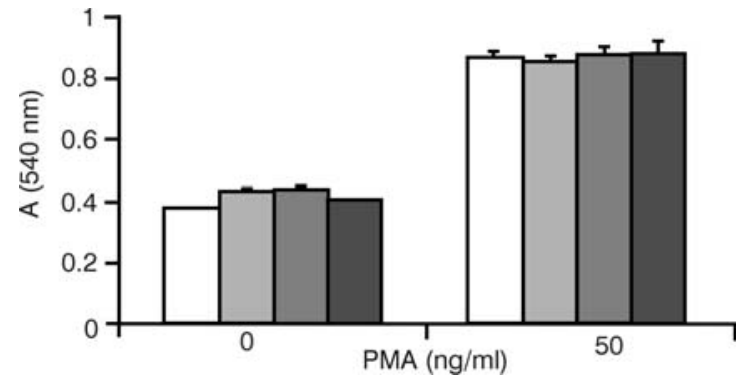

Figure 1. The effect of rhlL-17 on NBT reduction by human peripheral blood cells. WBC $(A)$, mononuclear cells $(B)$ and granulocytes $(C)$ were incubated with increasing concentrations of rhlL-17 in the absence or presence of PMA. NBT reduction is expressed as absorbance at $540 \mathrm{~nm}$. The results are presented as the mean \pm SE of triplicate samples from one experiment representative of four. 


\section{Effect of IL-17 on NO production by peripheral blood cells}

It is well known that inflammatory cytokines can stimulate peripheral blood leukocytes, predominantly mononuclear phagocytes and neutrophils, to produce NO. In order to evaluate NO production by human peripheral blood cells in the presence of rhIL-17, nitrite accumulation in 24h culture supernatants of WBC, granulocytes or mononuclear cells was determined. As presented in Figure 2, IL17 did not influence spontaneous or LPS-stimulated NO production by WBC. Moreover, rhIL-17 did not induce changes in spontaneous and LPS-stimulated NO production by peripheral blood mononuclear cells and granulocytes either (data not shown).

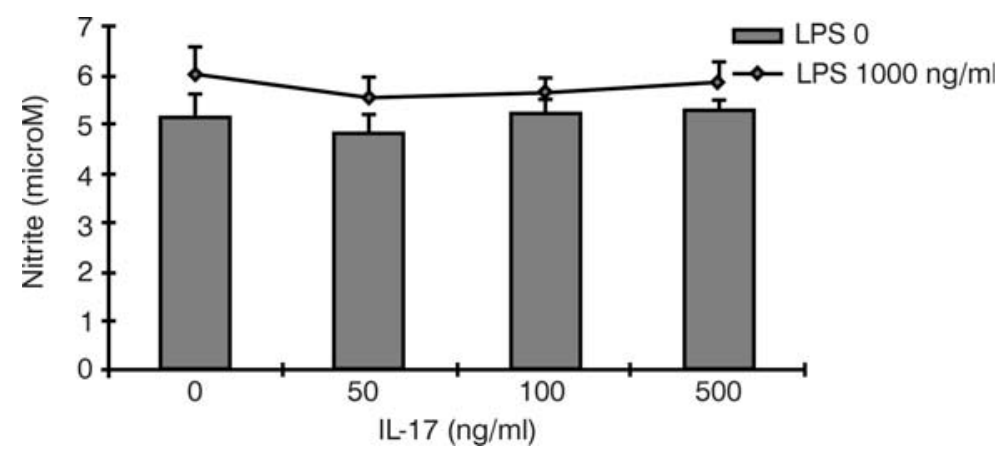

Figure 2. The effect of rhlL-17 on NO production by human peripheral blood cells. WBC were incubated with increasing concentrations of rhlL-17 in the absence or presence of LPS and nitrite accumulation in cell culture supernatants was determined after $24 \mathrm{~h}$. NO production is expressed as nitrite concentration $(\mu \mathrm{M})$. The results are presented as the mean \pm SE of three experiments each performed in triplicate.

\section{Effect of IL-17 on peripheral blood cell adhesion to plastic}

Plastic microtitre plates are widely used in the assessment of leukocyte function since the plastic surface behaves physiologically with respect to leukocyte adhesion (Forsyth and Levinsky, 1989; Oez et al., 1990). The adhesion to plastic of WBC, as well as mononuclear cells and granulocytes was determined in the presence of increasing concentrations of rhlL-17. No rhIL-17 concentration used induced changes in spontaneous adhesion of WBC, mononuclear cells or granulocytes (Figure 3). A slight, but statistically insignificant increase in PMAstimulated granulocyte adhesion was detected in the presence of rhIL-17 at 100 and $500 \mathrm{ng} / \mathrm{ml}$ (approximately $27 \%$ of the response determined with PMA alone). A similar increase in adhesiveness was observed in the population of mononuclear cells, but only at the highest concentration of rhlL-17 used (500 $\mathrm{ng} / \mathrm{ml}$ ). However, in WBC cultures no effect of rhlL-17 on PMA- stimulated adhesion was noted. 
Acta Veterinaria (Beograd), Vol. 54. No. 4, 249-261, 2004.

Vlaški Marija et al. Effects of IL-17 on functional activity

of peripheral blood cells

A

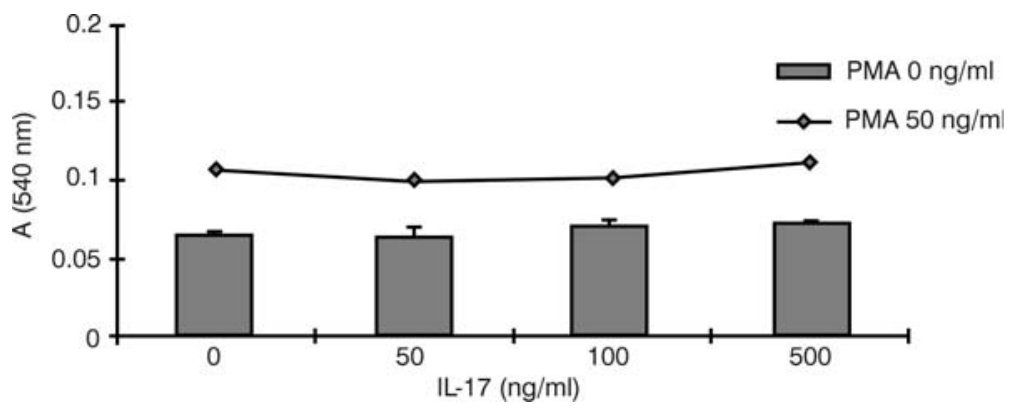

B

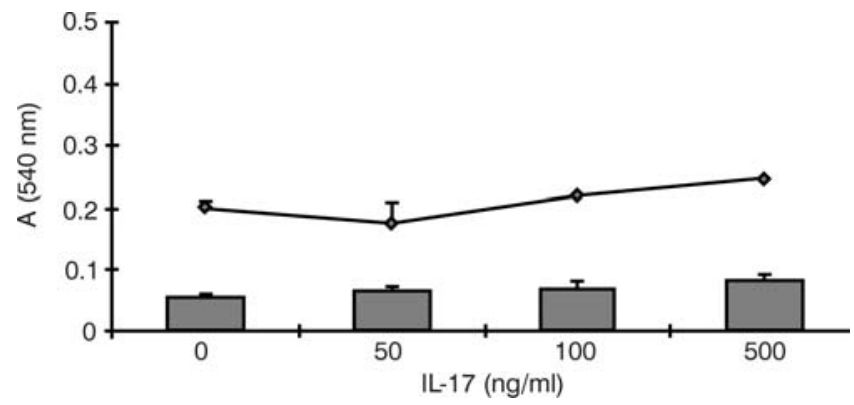

C

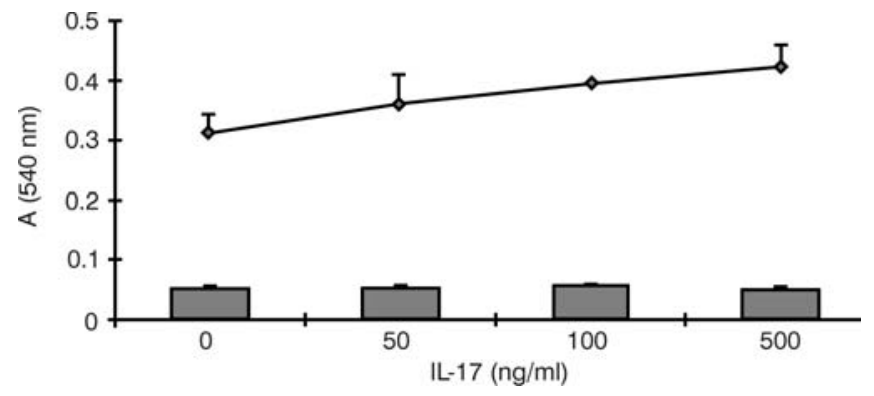

Figure 3. Figure 3. The effect of rhlL-17 on human peripheral blood cell adhesion to plastic. WBC (A), mononuclear cells (B) and granulocytes (C) were cultured with increasing concentrations of rhlL-17 in the absence or presence of PMA and adherence to plastic was measured after $60 \mathrm{~min}$ incubation at $37^{\circ} \mathrm{C}$. Adhesion is expressed as absorbance at $540 \mathrm{~nm}$. The results are presented as the mean \pm SE of triplicate samples from one experiment representative of four.

\section{Effect of IL-17 on MTT reduction by peripheral blood cells}

MTT is metabolically reduced exclusively by living cells and therefore it is recommended as a quantitative colorimetric assay for the measurement of cellular proliferation, viability and cytotoxicity (Mosmann et al., 1983). To estimate if rhIL-17 affected the metabolic activity/viability of peripheral white blood cells, we 
conducted the MTT assay with freshly isolated total WBC, granulocytes or mononuclear cells in the presence of increasing concentrations of rhIL-17, since only metabolically viable cells reduce soluble tetrazolim salt-MTT to insoluble formazan (Jabbar et al., 1989). None of the rhIL-17 concentrations tested induced any significant changes in the levels of MTT reduction by either examined peripheral blood cell fraction (Figure 4). The estimated levels of MTT reduction in the presence of rhlL-17 were no more than $10 \%$ different from the response observed with medium alone.

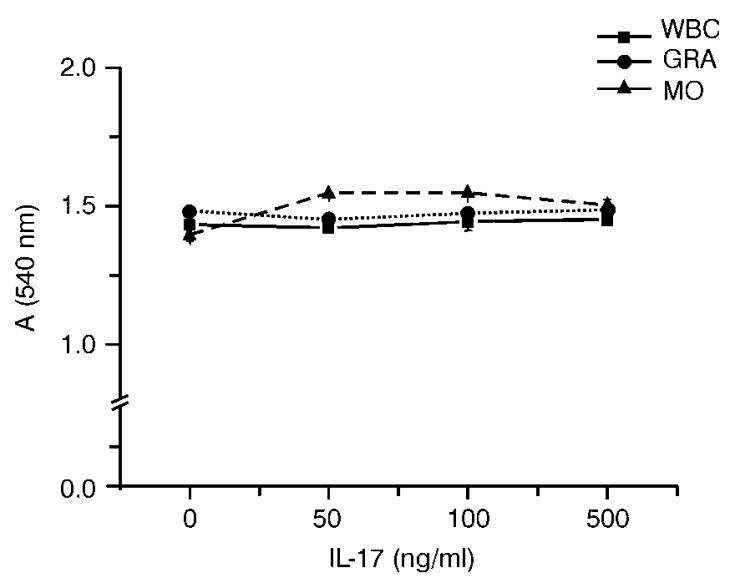

Figure 4. Figure 4. The effect of rhIL-17 on MTT reduction by human peripheral blood cells. Freshly isolated human peripheral WBC $(\mathbf{\square})$, mononuclear cells $(\boldsymbol{\Delta})$ and granulocytes $(\bullet)$ were exposed to increasing concentrations of rhlL-17 and MTT reduction was measured after $3 \mathrm{~h}$ incubation at $37^{\circ} \mathrm{C}$. MTT reduction is expressed as absorbance at $540 \mathrm{~nm}$. The results are presented as the mean \pm SE of triplicate samples from one experiment representative of three.

\section{DISCUSSION}

Peripheral blood leukocytes circulate in the vasculature in a passive, quiescent state. In the course of inflammation they are recruited to the site of inflammation, where they become activated by cytokines and inflammatory mediators to express their effector functions. IL-17 has been classified as a proinflammatory cytokine because of its ability to induce expression of many mediators of inflammation, but the data concerning its activity on peripheral blood leukocytes are limited. In this study we have examined if the proinflammatory activity of IL-17 can be extended to the functional activation of peripheral blood leukocytes, since this property of IL-17 may be of importance in the pathogenesis of chronic inflammatory diseases. 
Macrophages, neutrophils and other phagocytic cells are key components of the antimicrobial and tumoricidal immune responses, due to their capability to generate large amounts of highly toxic molecules - reactive oxygen (ROIs) and nitrogen intermediates (RNIs). The production of the oxygen radical, superoxide $\left(\mathrm{O}_{2}^{-}\right)$, is mediated by activation of respiratory burst NADPH oxidase. It is known that in resting cells NADPH oxidase is dormant and is activated upon stimulation by different mechanisms depending on the agonist used, either various cytokines or different microbial products, such as LPS, PMA, fMLP (N-formyl-methionylleucyl-phenylalanine). Proinflammatory cytokines, IL-1 $\alpha / \beta$, TNF $\alpha$, GM-CSF, IL-6 and IL-8, have been shown to interact with polymorphonuclear neutrophils (PMN) by stimulating the oxidative burst and/or exerting a priming effect, i.e. enhancing the PMN response to a secondary applied stimulus (Elbim et al., 1994). However, in our study IL-17 did not provoke any significant changes in respiratory burst activity of the total peripheral blood leukocytes, or granulocytes or mononuclear cells, either at the level of spontaneous or PMA-stimulated NBT reduction.

The production of NO, by inducible NO synthase (iNOS) enzyme, is also regulated by various inflammatory cytokines (TNF $\alpha$, IFN $\gamma$, IL-18, IL-1 $\alpha / \beta)$ and bacterial products (e.g. LPS) at transcriptional and posttranscriptional levels (Bogdan et al., 2000). IL-17 was previously reported to induce NO production in various cells, such as human chondrocytes, mouse osteoblasts, rodent astrocytes and endothelial cells (Miljković and Trajković, 2004). However, in our experiments no changes were detected in the basal levels of NO production by total WBC, granulocytes or mononuclear cells after $24 \mathrm{~h}$ incubation with rhlL-17. This is in agreement with the data demonstrating that human peripheral blood mononuclear phagocytes, neutrophils and T lymphocytes, produce no or little NO after various treatments in vitro (Weinberg et al., 1995; Webb et al., 2000; Arcos et al., 2003). Moreover, it was reported that IL-17 was unable to stimulate significant NO release in cultured human monocytes or rodent macrophages (Jovanovic et al., 1998; Trajković et al., 2001).

Circulating peripheral blood leukocytes are known to become more adhesive upon stimulation at the sites of inflammation. The adhesiveness of leukocytes to various matrices is used as an in vitro correlate of leukocyte adherence to endothelium or connective tissue (Oez et al., 1990). Numerous leukocyte functions dependent on adhesion are mediated by $\beta_{2}$ intergrins (CD11/CD18), normally expressed on the cell surface, although the relative abundance and the mode of CD11/CD18 avidity varies depending on the cell type and the state of cell activation and differentiation (Arnaout, 1990). The critical importance of the CD11/CD18 complex was also demonstrated for leukocyte adhesion to plastic (Schleiffenbaum et al., 1989). IL-17 in our experiments did not induce significant changes in the spontaneous adhesion of peripheral mononuclear cells and granulocytes, but a slight stimulation of adhesiveness was observed during the simultaneous presence of IL-17 and PMA. This finding pointed to a possible contribution of IL-17 in the priming of these cells. Previous data showed that various inflammatory mediators, such as TNF $\alpha$, IL-8, GM-CSF and $\mathrm{C5a}$ prime neutrophils to respond more effectively to a subsequent stimulation (Daniels et al., 1994; Hallet and Loyds, 1995). In this regard, it is 
possible that IL-17 can also prime peripheral blood granulocytes and mononuclear cells, probably by inducing changes at the level of signal transduction, enabling them to respond to PMA, as a secondary stimulus, with stronger adhesiveness.

The level of MTT reduction directly correlates with the number of metabolically active cells in the culture (Mosmann, 1983; Carmichael et al., 1987). Cellular bioreduction of MTT is associated with the activity of NADPH- and NADHdependent enzymes of the endoplasmatic reticulum, as well as mitochondrial succinate dehydrogenase. The production of reduced pyridine nucleotides during glucose metabolism was reported to be rate limiting for cellular MTT reduction (Berridge et al., 1996). Also, the critical role of glucose-6-phosphate dehydrogenase (G6PDH) activity, the rate-limiting enzyme of the glycolytic and pentose phosphate pathway, was emphasized in the regulation of cell death/survival (Tian et al., 1999). In this regard changes in MTT reduction were recommended as an assay for the assessment of the overall functional state of human polymorphonuclear leukocytes. According to our results obtained from the MTT assay it seems that rhIL-17 does not affect the overall metabolical activity of WBC, peripheral blood granulocytes and mononuclear cells from healthy persons.

The presented results demonstrate that IL-17 induced no or little changes in various functional activities of total peripheral blood leukocytes, granulocytes and mononuclear cells from normal subjects, suggesting that IL-17 does not express any proinflammatory ability in steady-state, since the requirement for its action really does not exist. This is consistent with data showing that IL-17 had no effect on the secretion of proinflammatory cytokines by blood monocytes (Fossiez et al., 1996), but stimulated the production and expression of IL-1 $\beta$ and TNF $\alpha$ only by activated macrophages (Jovanovic et al., 1998). In addition, this finding is in agreement with other studies reporting that leukocyte responsiveness to cytokines requires additional stimulation, such as adherence or combined action with other cytokines (Jovanovic et al., 1998; Nathan et al., 1989). This also may be a reason why circulating leukocytes are not routinely activated by the low level of circulating cytokines. Moreover, numerous reports have documented that IL-17 alone induce weak responses in various stromal cells, but emphasized its synergistic action with other proinflammatory cytokines, implying a possible role as a "fine-tuning" element in the complex cytokine network (Katz et al., 2001; LeGrand et al., 2001; Chabaud et al., 2001). In our previous study we demonstrated that the influence of IL-17 on hematopoietic progenitor cell growth and cytokine release was dependent on the physiological/pathological status of the organism and that IL-17 exerted a more prominent effect especially on cytokine secretion in post-irradiated murine bone marrow cells (Jovčić et al, 2001). Increased levels of IL-17 have been associated with some chronic inflammatory conditions, such as rheumatoid arthritis, (RA), in which circulating leukocytes exhibit several features indicative of partial activation (Edwards and Hallett, 1997). Since prior in vivo priming could alter subsequent leukocyte functions, our future studies will consider if IL-17 can modulate the functional 
activity of peripheral blood leukocytes obtained from patients with RA or other chronic inflammatory diseases.

\title{
ACKNOWLEDGEMENTS
}

This work was supported by a grant from the Ministry of Science, Technologies and Development, Republic of Serbia (project \#1742 "Regulation of Hematopoiesis and Biologically Active Molecules"). The excellent technical assistance of Mrs K. Božanić and Mrs S. Marković is appreciated.

\author{
Address for correspondence: \\ Mr Marija Vlaški \\ Institute for Medical Research \\ Dr Subotića 4, P.O.Box 102 \\ 11129 Beograd, Serbia \& Montenegro \\ e-mail: marija@imi.bg.ac.yu ; \\ alksandra@imi.bg.ac.yu
}

\section{REFERENCES}

1. Aggarwal S, Gurney AL, 2002, IL-17: prototype member of an emerging cytokine family, J Leukoc Biol, 71,1-8.

2. Albanesi C, Cavani A, Girolomoni G. 1999, IL-17 is produced by nickel-specific T lymphocytes and regulates ICAM-1 expression and chemokine production in human keratinocytes: synergistic or antagonist effects with IFN- $\gamma$ and TNF- $\alpha$. J Immunol, 162, $494-502$.

3. Arcos ML, Gorelik G, Klecha A, Goren N, Cerquetti C, Cremaschi GA, 2003, Inducible nitric oxide synthase-mediated proliferation of a T lymphoma cell line, Nitric Oxide, 8, 111-8.

4. Arnaout MA, 1990, Structure and function of the leukocyte adhesion molecules CD11/CD18. Blood, $75,1037-50$.

5. Berridge MV, Tan AS, McCoy KD, Wang R, 1996, The biochemical and cellular basis of cell proliferation assays that use tetrazolium salts, Biochemica, 4, 15-20.

6. Bogdan C, Rollinghoff M, Diefenbach A. 2000, The role of nitric oxide in innate immunity, Immunol Rev, 173, 17-26.

7. Carmichael J, DeGraff WG, Gazdar AE, Minna JD, Mitchell JB, 1987, Evaluation of a tetrazoliumbased semiautomated colorimetric assay assessment of chemisensitivity testing, Cancer Res, 17, 936-42.

8. Chabaud M, Page G, Miossec P, 2001, Enhancing effect of IL-1, IL-17, and TNF-alpha on macrophage inflammatory protein-3alpha production in rheumatoid arthritis: regulation by soluble receptors and Th2 cytokines, $J$ Immunol, 167, 6015-20.

9. Daniels RH, Elmore MA, Hill ME, Shimizu Y, Lackie JM, Finnen MJ, 1994, Priming of the oxidative burst in human neutrophils by physiological agonists or cytochalasin B results from the recruitment of previously non-responsive cells, Immunology, 82, 465-72.

10. Edwards SW, Hallett MB, 1997, Seeing the wood for the trees: The forgotten role of neutrophils in rheumatoid arthritis, Immunol Today, 18, 320-24.

11. Elbim C, Bailly S, Chollet-Martin S, Hakim J, Gougerot-Pocidalo MA, 1994, Differential priming effects of proinflammatory cytokines on human neutrophil oxidative burst in response to bacterial N-formyl peptides, Infect Immun, 62, 2195-201.

12. Forsyth KD, Levinsky RJ, 1989, Role of the LFA-1 adhesion glycoprotein in neutrophil adhesion to endothelium and plastic surfaces, Clin Exp Immunol, 75, 265-68.

13. Fossiez F, Djossou O, Chomarat P, Flores-Romo L, Ait-Yahia S, Maat $C$ et al. 1996, T cell interleukin17 induces stromal cells to produce proinflammatory and hematopoietic cytokines, J Exp Med 183, 2593-603.

14. Fossiez F, Banchereau J, Murray R, Van Kooten C, Garrone P, Lebecque S. 1998, Interleukin-17, Int Rev Immunol, 16, 541-51. 
15. Fujino S, Andoh A, Bamba S, Ogawa A, Hata K, Araki Y et al, 2003, Increased expression of interleukin 17 in inflammatory bowel disease, Gut, 52, 65-70.

16. Green LC, Wagner DA, Glogowski J, Skipper PL, Whishnok JS, Tannenbaum SR, 1982, Analysis of nitrate, nitrite and [ $\left.{ }^{15} \mathrm{~N}\right]$ nitrate in biological fluids, Anal Biochem, 126, 131-38.

17. Hallett MB, Lloyds D. 1995, Neutrophil priming: the cellular signals that say 'amber' but not 'green'. Immunol Today, 16, 264-68.

18. Jabbar SA, Twentyman PR, Watson JV, 1989, The MTT assay underestimates the growth inhibitory effects of interferons, Br J Cancer, 60, 523-28.

19. Jovanovic DV, Di Battista JA, Martel-Pelletier J, Jolicoeur FC, He Y, Zhang M et al, 1998, IL-17 stimulates the production and expression of proinflammatory cytokines, IL- $\beta$ and TNF- $\alpha$, by human macrophages, J Immunol, 160, 3513-21.

20. Jovčić G, Bugarski D, Petakov M, Stanković J, Stojanović N, Milenković P, 2001, Effect of IL-17 on in vitro hematopoietic progenitor cells growth and cytokine release in normal and post-irradiated murine bone marrow, Growth Factors, 19, 61-71.

21. Katz Y, Nadiv O, Beer Y, 2001, Interleukin-17 enhances tumor necrosis factor alpha-induced synthesis of interleukins 1,6 , and 8 in skin and synovial fibroblasts: a possible role as a "finetuning cytokine" in inflammation processes, Arthritis Rheum, 44, 2176-84.

22. Kotake S, Udagawa N, Takahashi N, Matsuzaki K, Itoh K, Ishiyama S et al,1999, IL-17 in synovial fluids from patients with rheumatoid arthritis is a potent stimulator of osteoclastogenesis, $J$ Clin Invest, 103, 1345-52.

23. LeGrand A, Fermor B, Fink C, Pisetsky DS, Weinberg JB, Vail TP et al. 2001, Interleukin-1, tumor necrosis factor alpha, and interleukin-17 synergistically up-regulate nitric oxide and prostaglandin E2 production in explants of human osteoarthritic knee menisci, Arthritis Rheum, 44, 2078-83.

24. Matusevicius D, Kivisakk P, He B, Kostulas N, Ozenci V, Fredrikson S et al, 1999, Interleukin-17 mRNA expression in blood and CSF mononuclear cells is augmented in multiple sclerosis, Mult Scler, 5, 101-4.

25. Miljković D, Trajković V, 2004, Inducible nitric oxide synthase activation by interleukin-17, Cytokine Growth Factor Rev, 15, 21-32.

26. Molet S, Hamid Q, Davoine F, Nutku E, Taha R, Page et al, 2001, IL-17 is increased in asthmatic airways and induces human bronchial fibroblasts to produce cytokines, J Allergy Clin Immunol, 108, 430-38.

27. Monboisse J-C, Garnotel R, Randoux A, Dufer J, Borel J-P, 1991, Adhesion of human neutrophils to and activation by type-I collagen involving a b2 integrin, $J$ Leukoc Biol, 50, 373-80.

28. Mosmann T, 1983, Rapid colorimetric assay for cellular growth and survival: application to proliferation and cytotoxicity assays, $J$ Immunol Meth, 65, 55-63.

29. Nathan C, Srimal S, Farber C, Sanchez E, Kabbash L, Asch A et al, 1989, Cytokine-induced respiratory burst of human neutrophils: dependence on extracellular matrix proteins and CD11/CD18 integrins, J Cell Biol, 109, 1341-49.

30. Oez S, Welte K, Platzer E, Kalden JR, 1990, A simple assay for quantifying the inducible adherence of neutrophils, Immunobiology, 180, 308-15.

31. Rouvier E, Luciani MF, Mattei MG, Denizot F, Golstein P, 1993, CTLA-8, cloned from an activated T cell, bearing AU-rich messenger RNA instability sequences, and homologous to a herpesvirus saimiri gene, J Immunol, 150, 5445-56.

32. Schleiffenbaum B, Moser R, Patarroyo M, Fehr J, 1989, The cell surface glycoprotein Mac-1 (CD11b/CD18) mediates neutrophil adhesion and modulates degranulation independently of its quantitative cell surface expression, J Immunol, 142, 3537-45.

33. Schwarzenberger P, Kolls JK, 2002, Interleukin 17: an example for gene therapy as a tool to study cytokine mediated regulation of hematopoiesis, J Cell Biochem Suppl, 38, 88-95.

34. Schwarzenberger P, La Russa V, Miller A, Ye P, Huang W, Zieske A et al, 1998, IL-17 stimulates granulopoiesis in mice: use of an alternate, novel gene therapy-derived method for in vivo evaluation of cytokines, J Immunol, 161, 6383-89. 
35. Teunissen MB, Koomen CW, de Waal Malefyt R, Wierenga EA, Bos JD. 1998, Interleukin-17 and interferon-gamma synergize in the enhancement of proinflammatory cytokine production by human keratinocytes, J Invest Dermatol, 111, 645-49.

36. Tian WN, Braunstein LD, Apse K, Pang J, Rose M, Tian X et al, 1999, Importance of glucose-6phosphate dehydrogenase activity in cell death, Am J Physiol Cell Physiol, 276, 1121-31.

37. Trajkovic V, Stosic-Grujicic S, Samardzic T, Markovic M, Miljkovic D, Ramic Z et al. 2001, Interleukin17 stimulates inducible nitric oxide synthase activation in rodent astrocytes, $J$ Neuroimmunol, 119, 183-91.

38. Webb JL, Polak JM, Evans TJ, 2001, Effect of adhesion on inducible nitric oxide synthase (iNOS) production in purified human neutrophils, Clin Exp Immunol, 123, 42-48.

39. Weinberg JB, Misukonis MA, Shami PJ, Mason SN, Sauls DL, Dittman WA et al. 1995, Human mononuclear phagocyte inducible nitric oxide synthase (iNOS): analysis of iNOS mRNA, iNOS protein, biopterin, and nitric oxide production by blood monocytes and peritoneal macrophages, Blood, 86, 1184-95.

40. Witowski J, Ksiazek K, Jorres A. 2004, Interleukin-17: a mediator of inflammatory responses, Cell Mol Life Sci, 61, 567-79.

41. Yao Z, Spriggs MK, Derry JM, Strockbine L, Park LS, VandenBos T et al, 1997, Molecular characterization of the human interleukin (IL)-17 receptor, Cytokine, 9, 794-800.

\title{
EFEKTI IL-17 NA FUNKCIONALNU AKTIVNOST ĆELIJA PERIFERNE KRVI
}

\author{
VLAŠKI MARIJA, KRSTIĆ ALEKSANDRA, JOVČIĆ GORDANA, BUGARSKI DIANA, \\ PETAKOV MARIJANA, STOJANOVIĆ NEVENKA i MILENKOVIĆ P
}

\section{SADRŽAJ}

Interleukin 17 (IL-17) je proinflamatorni citokin koga produkuju aktivirane CD4+ i CD8+ T ćelije, dok je njegov receptor ubikvitarno distribuiran. Inflamatorni kapacitet IL-17 se zasniva na njegovoj sposobnosti da stimuliše širok spektar stromalnih ćelija da produkuju i oslobađaju različite proinflamatorne medijatore, među kojima neki imaju efekte na hematopoezu, posebno granulopoezu. Dosadašnji podaci ukazuju na ulogu IL-17 u patogenezi različitih inflamatornih bolesti, odbacivanju transplanta i razvoju tumora. Cilj ovog rada je bio da se odrede funkcionalni odgovori, uključujući respiratorni prasak, produkciju azot monoksida (NO), adhezivnost i metaboličku aktivnost/vijabilnost različitih ćelija periferne krvi (ukupnih leukocita, mononuklearnih ćelija i granulocita) zdravih donora, u prisustvu IL-17. Dobijeni rezultati su ukazali da IL-17 ne dovodi do značajnih promena respiratornog praska, produkcije NO i metaboličke aktivnosti ćelija periferne krvi, ali da uzrokuje blago povećanje forbol-12-miristat-13-acetat (PMA) stimulisane adhezivnosti granulocita i mononuklearnih ćelija. Odsustvo značajnih promena $u$ ispitivanim funkcionalnim aktivnostima različitih ćelija periferne krvi, ukazuje da IL-17 ne eksprimira proinflamatorno dejstvo kod zdravih osoba, jer najverovatnije i ne postoji potreba za njegovim delovanjem. 